\title{
Influnce of Using Photographs in Descriptive Writing to the Students of Nursing
}

\author{
Fini Widya Fransiska \\ Fakultas Kesehatan Universitas Muhammdiyah Pringsewu \\ email: Hanayvinny56@gmail.com
}

\begin{abstract}
The objective of research was to know whether there was any influnces of using photographs in descriptive writing to the students of nursing. In fact, many nurse students still find difficulties in writing. They still find difficulties in expressing what they want to write and how to write. In overcoming those problems, in certain condition to interest them, teacher can use many media to help them producing good written. One of the media is the using of photograph in teaching learning writing. Photograph can make students find ideas in writing and it can help them to make descriptive text when they look the picture. The population was taken from the nurse students of Universitas Muhammadiyah Pringsewu. The writer took two classes for experiment and control. The data collecting technique used the writing test. The teacher gave some topics and the students had to make composition by choosing one of the topic. The analyzing the data, the writer used $t_{\text {test }}$. After calculated the data, the writer found that was use photographs was $x^{2}{ }_{\text {ratio }}=6.01$, and that was without use photographs was $x_{\text {ratio }}^{2}=3.93$. It can conclude there was any influence of using photographs in descriptive writing to the students of nursing. The writer suggested to English teacher should be use photographs as a media in teaching writing.
\end{abstract}

\section{Keywords:Effectivenes, photographs, writing}

\section{INTRODUCTION}

As human beings who live in the word, we need language to communicate with other people and one important thing in our life. By using it, we can know peoples' feeling, idea, opinion etc. not only that, but also we can share to other people by using language.

Language is a system of communication in speaking and writing used by people of particular country .It means that language is also as a tool of communication that only in spoken but also in written. It is used by people to communicate with other in certain place. Communication means understanding and conveying information and development knowledge, technology and culture used by people in certain country in Indonesia. It is first foreign languages all people study it. Now a day, it is an important language.

English has become a tool for international communication (Brown, 2001: 136). That is one reason why English cannot be separate from our daily lives. 
There were four skills namely: listening skill, speaking skill, reading skill and writing skill. As we know that writing is the last language skill. Writing skill proses is the witer can share, telling about feeling, and give imaginesion for reader.

Writing was difficult one and sometimes many students do not like it. They were confused what they want to write and materials were limited. The students feel difficult to make or write some sentences become story. The students only focus on one word by one word. The teacher should have many strategies in teaching English. Varying the instructional media and instructional material were needed. Many techniques, media and strategies can be done by English teaching.

The teacher guides and facilitates the students to get the message transmitted, and creating the conducive classroom such as: the classroom seat, the assessment, the learning activities, has a responsibility to create a good stimulation, guidance, direction and supporting the students well. In other side, the teacher also makes the students do not depend on the teacher itself who manage them continuously.

Preliminary data at nurse students of health faculty University of Muhammadiyah Pringsewu, the writer asked to one the students about this problem face many of the problems listed above. She said that writing has the most difficult from other skills, she found that the students felt difficult to write or make composition. They found difficulties in learning writing a story or it was known by descriptive text.
Liem said that: "the purpose of teaching foreign language is to enable the students to use the language in communication". (Liem, 1975:3). Teacher in class not only give theory but also give them a lot of time to practice make some story.

Based on the statement above, resercher try to find a new media for nurse. It can make the new condition in class and make them creative and active. The teacher must to know what they want.

Photograph is one of new media can used for writing easly. Photograph as can be used in writing. The students can look the picture and help them to find a new vocabulary.

Arif (2009: 29-49) based on the classification of visual media as the learning media, picture as one of visual medium consists of several types. They are as follow: Photo/ image are an image captured by means of photograph. It is the common language which can be understood, and enjoyed everywhere, Sketch is a simple picture, or a rough draft describing the main part without detail, Diagram is a simple picture using lines and symbols, and it describes the object in broad outline, Chart is a tool for presenting ideas or concepts that are difficult if only in writing or orally conveyed verbally, Graphs is a simple picture using dots, lines, or complete image sometime verbal symbol or also use there, Cartoon is interpretative used of symbols to convey a message quickly and succinctly, or an attitude toward people, situation, or certain events, Poster is an image that conveys certain impression, able to influence and 
motivate people's behaviors whom see it.

From statement above the resercher can conclude that photograph one of media to student can make descriptive text with a good composition. When they confused, they can see the picture details with colorful they can try to describing one person, or place. Photograph can make students enjoy in writing. They can be fun in that activity. In addition story circle can develop students' writing fluency.

Photogrpah one of descriptive writing techniques which aims to explain or describe something that is seen, heard, or felt. Ehrenhaft (2006:130) said that descriptive writing usually relies on sense impressions-records of what the eye sees, the ear heard, the nose smell, the tongue tastes, and the skill feel.

Descriptive writing produces create a visual image of people, voice, mood, place, even of units of time days, or reason, describe more than the outward appearance of people and tell about their trait of character or personality

Photograph was collaborate with descriptive writing.

From the background of problem The writer assumed that the using of photograph media in make a story gave the influence to the students' writing abilities.

\section{METHOD}

The writer investigated the data which were obtained after giving the treatment to the subject and analyzed the descriptive wirting which is influenced by the use of photograph.
Control class and experimental class got a pre test before treatment was conducted and got a post test after the treatment was administered.

The population in this research was taken from the nurse students of Universitas Muhammdiyah Pringsewu. The sample of research used two classes. The first class was experiment consis of 40 students and the second class was control consis of 38 students. In collecting data the writer gave the test. After the writer got the result from the research the writer analyzed the data.

In this research used t-test to know hypotesis and the influnces of using photographs in descriptive writing to the students of nursing.

1.

$$
\bar{X}=\frac{\sum X i}{n}
$$

2. Variance $\left(\mathrm{S}^{2}\right)$ calculated by formula

$$
=\frac{n\left(\sum f \cdot X^{2}\right)-\left(\sum f \cdot X\right)^{2}}{n(n-1)}
$$

To know the hypothesis, writer does this step, whether any different between the averages of the students' writing ability that are touch by using photograph.

The formula of t-test as follow:

$$
t_{\text {test }}=\frac{\overline{X_{1}}-\overline{X_{2}}}{S \sqrt{\frac{1}{n_{1}}+\frac{1}{n_{2}}}}
$$

$$
S^{2}=\frac{\left(n_{1}-1\right) s_{1}^{2}\left(n_{2}-1\right) s_{2}^{2}}{n_{1}+n_{2}-2}
$$

Testing criterion is $\mathrm{H}_{0}$ accepted if $t_{1}-1 / 2 \alpha<t<t_{1}-1 / 2 \alpha$ 
$d f={ }^{\left(n_{1}+n_{2}-2\right)}$ another $\mathrm{H}_{0} \quad$ value rejected

\section{FINDINGS AND DISCUSSION}

In collecting data the writer gave the test. The test was given to the samples which consist of two classes.

\subsection{Descriptive Statistics of Data}

\subsubsection{The Normality Test of Experiment Class}

The table of the score of the students', it was obtained the highest score $=85$ and the lowest $\mathrm{score}=45$ from $n=40$

The highest score $\quad=85$

The lowest score $\quad=45$

$\mathrm{n} \quad=40$

Span $(\mathrm{K})=$ the highest - the lowest score

$$
\begin{aligned}
& =85-45 \\
& =40
\end{aligned}
$$

Total number of interval class $(\mathrm{K})$

$$
\begin{aligned}
& =1+3.3 \log \mathrm{n} \\
& =1+3.3 \log 40 \\
& =1+3.3(1.6021) \\
& =1+5.286 \\
& =6.286 \\
& =6
\end{aligned}
$$

Length of Interval Class $=\frac{R}{K}$

$$
\begin{aligned}
& =\frac{40}{6} \\
& =6.67 \\
& =7
\end{aligned}
$$

Table 1. Distribution list of frequency of test result of experimental class

\begin{tabular}{cccccc}
\hline $\begin{array}{l}\text { SCOR } \\
\mathbf{E}\end{array}$ & $\mathbf{F}_{\mathbf{i}}$ & $\mathbf{X}_{\mathbf{i}}$ & $\mathbf{X}_{\mathbf{i}}{ }^{2}$ & $\mathbf{F}_{\mathbf{i}} \cdot \mathbf{X}$ & $\mathbf{F}_{\mathbf{i}} \cdot \mathbf{X}_{\mathbf{i}}{ }^{2}$ \\
\hline $\mathbf{4 5 - 5 1}$ & 3 & 48 & 2304 & 144 & 6912 \\
$\mathbf{5 2 - 5 8}$ & 3 & 55 & 3025 & 165 & 9075 \\
$\mathbf{5 9 - 6 5}$ & 7 & 62 & 3844 & 434 & 26908 \\
$\mathbf{6 6 - 7 2}$ & 8 & 69 & 4761 & 552 & 38088 \\
$\mathbf{7 3 - 7 9}$ & 1 & 76 & 5776 & 760 & 57760 \\
$\mathbf{8 0 - 8 6}$ & 0 & 83 & 6889 & 747 & 62001 \\
& 9 & & & & \\
Total & $\mathbf{4}$ & $\mathbf{3 9}$ & $\mathbf{2 6 5 9}$ & $\mathbf{2 8 0}$ & $\mathbf{2 0 0 7 4}$ \\
$(\Sigma)$ & $\mathbf{0}$ & $\mathbf{3}$ & $\mathbf{9}$ & $\mathbf{2}$ & $\mathbf{4}$ \\
\hline
\end{tabular}

So it can be searched the average and standard deviation as follows:

$$
\begin{aligned}
\overline{X_{1}} & =\frac{\sum f_{i} \cdot X_{i}}{\sum f_{i}} \\
& =\frac{2802}{40} \\
& =70.05
\end{aligned}
$$

Standard deviation:

$$
\begin{aligned}
& =\frac{40(200744)-(2802)^{2}}{40(40-1)} \\
& =\frac{8029760-7851204}{1560} \\
& =\frac{178556}{1560} \\
& =114.46 \\
S_{1} & =\sqrt{114.46} \\
& =10.70
\end{aligned}
$$

The next step is determining the Expected Frequency $\left(\mathrm{E}_{\mathrm{i}}\right)$ and the perception Frequency $\left(\mathrm{O}_{\mathrm{i}}\right)$ as follows:

1) Determining the boundary of the class (x) by subtracting the lowest score in the class by 0.5 .

2) Calculating $Z$ for the boundary of class with the formula

$$
z=\frac{X-\bar{X}}{S}
$$


3) Calculating the interval class, it is see $\mathrm{Z}$ value list.

4) $E_{i}=L_{i} \cdot n$

Table 2. distribution of expected and absorbed Frequency of experimental class

\begin{tabular}{llllcc}
\hline $\mathbf{X}$ & $\mathbf{Z}$ & $\mathbf{Z}_{\mathbf{i}}$ & $\mathbf{L}_{\mathbf{i}}$ & $\mathbf{E}_{\mathbf{i}}$ & $\mathbf{O}_{\mathbf{i}}$ \\
\hline $\mathbf{4 4 . 5}$ & -2.39 & 0.4916 & 0.0334 & 1.336 & \\
$\mathbf{5 1 . 5}$ & -1.73 & 0.4582 & 0.0983 & 3.932 & 3 \\
$\mathbf{5 8 . 5}$ & -1.08 & 0.3599 & 0.1935 & 7.74 & 3 \\
$\mathbf{6 5 . 5}$ & -0.43 & 0.1664 & 0.2574 & 10.296 & 7 \\
$\mathbf{7 2 . 5}$ & 0.23 & 0.0910 & 0.2196 & 8.784 & 8 \\
$\mathbf{7 9 . 5}$ & 0.88 & 0.3106 & 0.1276 & 5.104 & 10 \\
$\mathbf{8 6 . 5}$ & 1.54 & 0.4382 & & & 9
\end{tabular}

Determining $\mathrm{X}^{2}$ ratio by using the following formula:

$$
\chi_{\text {ratio }}^{2}=\sum_{i=1}^{k} \frac{(O i-E i)^{2}}{E i}
$$

The formula uses Chi-square ratio $\chi^{2}$ ratio

$$
\begin{aligned}
& \chi_{\text {ratio }}^{2} \\
& =\frac{(3-1.336)^{2}}{1.336}+\frac{(3-3.932)^{2}}{3.932}+\frac{(7-7.74)^{2}}{7.74} \\
& +\frac{(8-10.296)^{2}}{10.296}+\frac{(10-8.784)^{2}}{8.784}+\frac{(9-5.104)^{2}}{5.104} \\
& \quad= \\
& \quad 2.07+0.22+0.07+0.51+0.17+2.97 \\
& =6.01
\end{aligned}
$$

\section{The Testing criterion:}

Reject Ho if $x_{c a l}^{2}>x^{2}{ }_{t a b}$

For the significance level of 5\%

$(\alpha=0.05)$ obtained: 7.81

For the significance level of $1 \%$ $(\alpha=0.01)$ obtained:

For $\alpha=0.01=11.3$

It seen that $x_{\text {cal }}^{2}<x_{\text {tab }}^{2}$, so Ho is accepted which means that the data have normal distribution.

\subsubsection{The Normality Test of Control Class}

Table 3. The Distribution List Of Frequency Of Test Result Of Control Class

\begin{tabular}{cccccc}
\hline SCORE & $\mathbf{F}_{\mathbf{i}}$ & $\mathbf{X}_{\mathbf{i}}$ & $\mathbf{X}_{\mathbf{i}}^{\mathbf{2}}$ & $\begin{array}{c}\mathbf{F}_{\mathbf{i}} \mathbf{X} \\
\mathbf{i}\end{array}$ & $\mathbf{F}_{\mathbf{i}} \cdot \mathbf{X}_{\mathbf{i}}{ }^{2}$ \\
\hline $\mathbf{3 5 - 4 1}$ & 3 & 38 & 1444 & 114 & 4332 \\
$\mathbf{4 2 - 4 8}$ & 4 & 45 & 2025 & 180 & 8100 \\
$\mathbf{4 9 - 5 5}$ & 6 & 52 & 2704 & 312 & 16224 \\
$\mathbf{5 6 - 6 2}$ & 1 & 59 & 3481 & 590 & 34810 \\
$\mathbf{6 3 - 6 9}$ & 0 & 66 & 4356 & 528 & 34848 \\
$\mathbf{7 0 - 7 6}$ & 8 & 73 & 5329 & 511 & 37303 \\
& 7 & & & & \\
TOTAL $\left(\sum\right.$ & $\mathbf{3}$ & $\mathbf{3 3}$ & $\mathbf{1 9 3 3}$ & $\mathbf{2 2 3}$ & $\mathbf{1 3 5 6 1}$ \\
$\mathbf{)}$ & $\mathbf{8}$ & $\mathbf{3}$ & $\mathbf{9}$ & $\mathbf{5}$ & $\mathbf{7}$ \\
\hline
\end{tabular}

$$
\begin{aligned}
& =\frac{2235}{38} \\
& =58.82
\end{aligned}
$$

Standard deviation:

$$
\begin{aligned}
& =\frac{38(135617)-(2235)^{2}}{38(38-1)} \\
& =\frac{5153446-4995225}{38.37} \\
& =\frac{158221}{1406} \\
& =112.53 \\
S_{2} & =\sqrt{112.53} \\
& =10.61
\end{aligned}
$$

Table 4. Distribution of frequency control class

\begin{tabular}{|l|l|l|l|l|l|}
\hline $\mathbf{X}$ & $\mathbf{Z}$ & $\mathbf{Z}_{\mathbf{i}}$ & $\mathbf{L}_{\mathbf{i}}$ & $\mathbf{E}_{\mathbf{i}}$ & $\mathbf{O}_{\mathbf{i}}$ \\
\hline 34.5 & -2.29 & 0.4890 & & & \\
41.5 & -1.63 & 0.4484 & 0.0406 & 1.5428 & 3 \\
48.5 & -0.97 & 0.3340 & 0.1144 & 4.3472 & 4 \\
55.5 & -0.31 & 0.1217 & 0.2123 & 8.0674 & 6 \\
62.5 & 0.35 & 0.1368 & 0.2585 & 9.823 & 10 \\
\hline
\end{tabular}

| ELT-Lectura: Studiesand Perspectives in English Language Teaching Copyright@ 2020 FiniWidyaFransiska 


\begin{tabular}{|l|l|l|l|l|l|}
\hline 69.5 & 1.01 & 0.3438 & 0.1087 & 4.1306 & 7 \\
76.5 & 1.67 & 0.4525 & & & \\
\hline
\end{tabular}

Determining $\mathrm{X}^{2}$ ratio by using the following formula:

$$
\chi_{\text {ratio }}^{2}=\sum_{i=1}^{k} \frac{(O i-E i)^{2}}{E i}
$$

The formula uses Chi-square ratio

$$
\begin{aligned}
& \quad\left(\chi_{\text {ratio }}^{2}:\right. \\
& \chi_{\text {ratio }}^{2} \\
& =\frac{(3-1.5428)^{2}}{1.5428}+\frac{(4-4.3472)^{2}}{4.3472}+\frac{(6-8.0674)^{2}}{8.0674} \\
& +\frac{(10-9.823)^{2}}{9.823}+\frac{(8-7.866)^{2}}{7.866}+\frac{(7-4.1306)^{2}}{4.1306} \\
& = \\
& 1.38+0.03+0.53+0.00+0.00+1.99 \\
& =3.93
\end{aligned}
$$

The Testing criterion:

Reject Ho if $x_{\text {cal }}^{2} \geq x_{\text {tab }}^{2}$

For the significance level of $5 \%$ $(\alpha=0.05)$ obtained:

$(1-\alpha)(k-3)$ for $\alpha=0.05$

$$
\chi_{\text {ratio }}^{2}=7.81
$$

For the significance level of $1 \%$ $(\alpha=0.01)$ obtained:

For $\alpha=0.01$

$$
\chi_{\text {ratio }}^{2}=1.3
$$

$\mathrm{I} x_{\text {cal }}^{2}<x_{\text {tab }}^{2}$, so Ho is accepted. It has normal distribution.

\subsubsection{The Homogeneity Test}

$$
\begin{aligned}
& \mathrm{F}_{\text {hit }}=\frac{\text { The highest variance }}{\text { The lowest variance }} \\
& \begin{aligned}
F & =\frac{114.46}{112.53} \\
& =1.02
\end{aligned}
\end{aligned}
$$

With the test criterion:
For $\alpha=0.05$ obtained $\mathrm{F}_{\text {table }}$ $=\mathrm{F}^{1} \mathbf{1} 2.0 .05(39.37)$ $=1.69$

For $\alpha=0.01$ obtained $\mathrm{F}_{\text {table }}=$ $\mathrm{F} 1 / 2.0 .01(39.37)=1.71$

The data was homogeneous

\subsubsection{The Hypothesis Test}

$$
\begin{aligned}
\mathrm{n}_{1} & =40 \\
\frac{\mathrm{n}_{2}}{X_{1}} & =38 \\
\frac{X_{2}}{X_{1}^{2}} & =50.05 \\
S_{2}^{2} & =10.70 \\
S^{2} & =10.61 \\
= & \frac{(40-1) 114.46+(38-1) 112.53}{40+38-2} \\
= & \frac{(39) 114.46+(37) 112.53}{76} \\
= & \frac{4463.94+4163.61}{76} \\
= & \frac{8627.55}{76} \\
= & 113.52 \\
S= & \sqrt{113.52} \\
= & 10.65
\end{aligned}
$$

The value is included into the $\mathrm{t}_{\text {test }}$ formula as:

$$
\mathrm{t}=\frac{75.05-58.82}{10.65 \sqrt{\frac{1}{40}+\frac{1}{38}}}
$$

$$
\begin{aligned}
\mathrm{t} & =\frac{11.23}{10.65 \sqrt{0.04+0.02}} \\
\mathrm{t} & =\frac{11.23}{10.65 \sqrt{0.06}} \\
\mathrm{t} & =\frac{11.23}{10.65(0.24)} \\
& =\frac{11.23}{2.56}
\end{aligned}
$$




$$
=4.39
$$

Ho is accepted if $t_{\text {test }}>t_{\text {tab }}(1-112 \alpha)$ with $\mathrm{dk}\left(\mathrm{n}_{1}+\mathrm{n}_{2}-2\right)$

$$
\begin{aligned}
\mathrm{dk} & =\mathrm{n}_{1}+\mathrm{n}_{2}-2 \\
& =40+38-2 \\
& =76
\end{aligned}
$$

For $5 \%(\alpha=$ or 0.05$)$ it is obtained:

$$
\begin{aligned}
\mathrm{t}_{\mathrm{tab}} & =(1-1 \backslash 2 \alpha)(\mathrm{dk}) \\
& =(1-1 \backslash 2.0 .05)(76) \\
& =(0.975)(76) \\
& =1.99
\end{aligned}
$$

For $1 \%(\alpha=0.01)$ it is obtained:

$\mathrm{t}_{\mathrm{tab}}=2.64$

It means that $\mathrm{t}_{\text {test }}>\mathrm{t}_{\text {tab }}$ so $4.39>1.99$ and 2.64. Hypothesis was accept because $t_{1-}$ $1 / 2 \alpha<\mathrm{t}<\mathrm{t}_{1-1 / 2 \alpha}$.

After we got the result of $\mathrm{t}_{\text {test }}=4.39, \mathrm{t}_{\mathrm{tab}}=$ 1.99 and 2.64, the hypotheses are:

$\mathrm{H}_{0}: \mu_{1}=\mu_{2} \quad$ (There was no influnces of using photographs in descriptive writing to the students of nursing)

$\mathrm{H}_{\alpha}: \mu_{1} \neq \mu_{2} \quad$ (There was influnces of using photographs in descriptive writing to the students of nursing)

From the result above, the writer stated that there is influnces of using photographs in descriptive writing to the students of nursing

\subsubsection{Difference Hypotheses Two Averages}

Ho is accepted if $t_{\text {cal }} \geq t_{t a b}$, with $t_{\text {tab }}=t(1-$ a) (dk)

By looking $\mathrm{G}$ table, we can find $\mathrm{t}_{\mathrm{tab}}$ for $\alpha=5 \%$ or 0.05

$$
\mathrm{t}_{\mathrm{tab}}=1.67
$$

$\mathrm{t}_{\mathrm{cal}}=4.39$ and $\mathrm{t}_{\mathrm{tab}}=1.67$ it is attained that

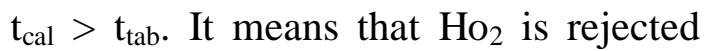
andHa $\mathrm{Ha}_{2}$ is accepted. There was any positive and significant of who are taught writing using photograph.

\section{CONCLUSION}

The writer gives the conclusions:

1. Photograph make or write a composition easily and there is influnces of using photographs in descriptive writing to the students of nursing.

2. There is positive and significant influnces of using photographs in descriptive writing to the students of nursing. It was $t_{\text {ratio }}=4.39$ and $t$ tab $=$ 1.67 it was attained that $\mathrm{t}_{\mathrm{cal}}>\mathrm{t}_{\mathrm{tab}}$.

3. The students score by using photograph was higher than without photograph. The score of experimental class was $\overline{\mathrm{X}}=$ 70.05 and the score of control class was $\overline{\mathrm{X}}=58.82$.

4. The students were enjoyed the teaching activity by using Photograph and teaching writing by using giving photograph is able to increase in writing skill.

\section{SUGGESTION}

\section{Teacher}

In teaching writing, teachers should used multiple media and tactics, such as: the photographs. By using this media, the students enjoy in writing a composition or story and understand the lesson easier. The students can share their ideas and interact more frequently.

The teacher should pay attention to their students' understanding about parts of text. The teacher should ladder tasks so that the students can improve their grammar, by beginning with simple task 
to complex concepts. The teacher checks the students' task or exercise directly in order to make the students' know their mistakes immediately. The photographs can be used to teach writing in the classroom.

\section{Students}

a. They must have high motivation to learn and practice especially in writing by loving the subject first.

b. The students must listen when the teacher give explainnation in the materials. Don't frighten to ask and try to make sentence

\section{School}

a. School gives more supporting equipment, such as language laboratory, adding the English literature books in the library or by doing more activities,

b. It is good mentality and motivation and by making agenda of English Competition among the classes and to follow the English Competition in order department (out of school).

c. The headmaster should not be afraid to adopt new method or technique that is used to teaching in the classroom. The school should provide more facilities, such as: a language laboratory, add more English literature books in the library, and by doing English competitions in order to encourage students to learning English. Student's motivation for learning English should be encouraged by adopting new media.

\section{REFERENCES}

Anderson, Mark \& Anderson, Kathy. 2003. Text Types in English 2. Auatralia: Macmillan Education Australia Pty Ltd.

Ann Kipfer, Barbara. 2001. Random House Webster's College Dictionary. New York: Random House.

Arif S Sadiminet, al. 2009. Media Pendidikan: Pengertian, Pengembangan, danPemanfaatannya. Jakarta: Raja GrafindoPersada.

Ary, Donald \& Sorensen, C. 2010.Introduction to Research in Education ( $8^{\text {th }}$ edition). Canada: Cengage Learning.

AzharArsyad. 2009. Media Pembelajaran. Jakarta: Raja GrafindoPersada.

Bowker, Natiline. 2007. Academic Writing: a Guide to Tertiary Level Writing. Massey University: Student Life Palmersthon North.

Brown, H. 2001. Teaching by Principles and Interactive Approach to Language Pedagogy. England: Prentice Hall, Inc.

-------. 2007. Principles of Language Learning and Teaching. New York: Longman.

Byrne, Donn. 1995. Teaching Writing Skills. New York: Longman.

Creswell, J.W. 2008.Educational Research: Planning, Conducting 
AndEvaluating Quantitative and Qualitative Research. New Jersey: Pearson International Edition

Crowl, K. Thomas. 1996. Fundamentals of Educational Research. United States of America: Times Mirror Higher Education Group.

Dullay, Heidi et al. 1982. Language Two.New York: Oxford University Press.

Djiwandon, Soenardi. 2011. TesBahasa; PeganganbagiPengajarBahasa. Jakarta: Indeks.

EndangFauziati. 2010. Teaching English as a foreign language (TEFL). Surakarta: PT. Era PustakaUtama.

Ehrenhaft, George. 2006. ACT 2007. 14 ${ }^{\text {th }}$ Edition. USA: Barron's Educational Series, Inc

Fergenson, Laraine and Nickerson, Marie-Louse. 1998. All in One: Basic Writing Text, Workbook, and Reader. New Jersey: Marie-Louse Prentice Hall.

Finocchiaro, Mary. 1989. Teaching English as Foreign Language. New York: Oxford University Press.

Gebhardt, R.C. and Rodrigues,D. 2000. Writing Processes and Intention. Lexington: D.C. Health and Company.

Greene, Ellin. 1996. Storytelling.Art and Technique.Third Edition. USA: Greenwood.

Harmer, J. 2007.The Practice of English Language Longman
Teaching.London:
2004. How to Teach Writing. London: Pearson Education Limited.

Harris, David. 1996. Testing English as a Second Language. London: MC Graw- Hill Book Company.

Heaton, J.B. 1987. Language Testing. London: Longman.

Hornby, A.S. 2005. Oxford Advance Learners Dictionary. Oxford: Oxford University Press.

Hughes, Arthur. 2003. Testing for Language Teachers. United Kingdom: Cambridge University Press.

Hutchinson, Emily. 2005. Descriptive writing: Development and production. United States of America: Times Saddleback Laurel Associates Educational Group.

Hyland, Ken. 2003. Second Language Writing. New York: Cambridge University Press.

2009. Teaching and Researching Writing. Great Britain: Pearson Education.

Jaya, Alexander Mongot, et al. 2007. English Revolusioner.Jepara: Mawas Press.

Kimberlin, Carole L and Winterstein, Almut G. 2008.Validity and Reliability of Measurement Instruments Used in Research. Florida: Am J Health-Syst Pharm.

Levine, Melvin. 1993. Developmental Variation and LearningDisorders. Retrieved from her wibsite: 
https://www.pbs.org/wgbh/misunder stoodminds/writingdiffs.html.

Accessed on Monday, April 27, 2014, at 20:00

Liderman, Erika 1983. A Rhetoric for Writing Teaching. USA: Oxford of Chicago Press.

Lynch, Brian K. 1996. Language Program Evaluation: Theory and Practice. New York: Cambridge University Press.

Marlow, Patrick and Siekmann, Sabine. 2013. Community of Practice. USA: The University of Arizona Press.

Mary, Fitzpatrick. 2005. Engaging writing: Paragraphs and Essays. London: Longman.

Mckay, and Penny. 2006. Assessing Young Language Learners. New York: Cambridge University Press.

Nasser Saleh Al-Mansour \&Ra'edAbdulgader, Al-Shorman. 2011. The effect of teacher's storytelling aloud on the reading comprehension of Saudi elementary stage students. Journal of King Saud University Languages and Translation, 23, page 69-76

Nation, I.S.P. 2009.Teaching ESL/EFL Reading and Writing. New York: Routledge.

Nunan, David. 2003. Practical English Language Teaching. Singapore: Mc Graw Hill.

------. 2005. Research Methods in Language Learning. New York: Cambridge University Press.
Oshima, Alice and Hogue, Ann. 2006. Writing Academic English $\left(4^{\text {th }}\right.$ Edition). New York: Pearson Education, Inc.

Ramelan. 1994. Introduction to Linguistic Analysis. Semarang: IKIP Semarang Press.

Raimes, Ann. 1983.Techniques in Teaching Writing. China: Oxford University Press.

Richards, J.C. \&Renandya. 2003. Methodology in Language Teaching: An Anthology of Current Practice. New York: Cambridge University Press

Sekaran, Uma. 2002. Research Methods for Business: A Skill Building Aproach. New York: John Wiley \& Sons, inc.

Selinger, H.W and Shohamy,E. 1989. Second Language Research Method. Oxford: Orford University.

Seyed,JalalAbdolmanafi-

Rokni\&Masoud,Qarajeh. 2014. Digital storytelling in EFL classrooms: The effect on the oral performance. International Journal of Language and Linguistics, 2(4), page $252-257$

Suharsimi, $\quad$ Arikunto. 2010. ProsedurPenelitian:

SuatuPendekatanPraktik. Jakarta: PT. RinekaCipta.

Sugiyono.

2013. MetodePenelitianKuantitatifKualitat if dan $R \& D$. Bandung: ALFABETA

Spencer, L. 2005. A step by step Guide to Issue Based Writing. New York: The Rosen Publishing Group. 
Terrible, C. 1996.Language Teaching. A Scheme for Teacher Education: Writing. New York: Oxford University Press.

Ur, P. 1991. A Course in Learning Teaching: Practice and Theory. Cambridge: University Press

Yudantoro, Elang. 2010.

Rangkumanbahasainggris SMA. Jakarta: Gagas Media. 